\title{
The accuracy and ease with which measurements of respiratory metabolism can be made with tracheostomized sheep
}

\author{
By K. L. BLAXTER AND J. P. JOYCE \\ Hannah Dairy Research Institute, Ayr

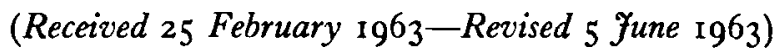

In developing methods to study the effect of the outdoor environment on the metabolism of sheep, we required a method for estimating heat production continuously over several hours. The fitting of a permanent tube in the trachea seemed ideal for this purpose, and this paper summarizes experiments carried out to test the validity of the technique. A second paper describes experiments on the effect of environmental factors using this method of measuring metabolism (Joyce \& Blaxter, 1964). Tracheostomized sheep, cattle and horses have been used as experimental subjects since the I 880 os as reviewed by Flatt, Waldo, Sykes \& Moore (I958) and, more recently, Webster \& Cresswell (1957), working with sheep, have used the method with success. Only one adequate test of the validity of the method has been traced. Klein (I915) compared estimates of the oxygen consumption and carbon dioxide and methane production of a tracheostomized bull made in respiration chambers of the open- and closed-circuit types with those made from the pulmonary exchange alone. He concluded that a large part of the $\mathrm{CH}_{4}$ produced in the gut was not excreted by the lung. No experiments to find the extent of and variation in the pulmonary loss of gas formed in the gut with diet and other factors have been traced.

\section{EX P E R I MEN T A L}

\section{Animals}

Eight wether sheep were used as experimental animals. They were all over 4 years of age and the breeds included Scottish Blackfaces, Cheviots and Down crosses.

\section{Establishment of tracheal fistulas}

The technique of complete transection of the trachea developed with cattle by Colvin, Wheat, Rhode \& Boda (1957) and used successfully by Flatt et al. (1958) was used unsuccessfully with one sheep. The trachea was transected, one cartilaginous ring removed and the distal and cranial ends were sutured to the skin. When the operation was complete a thin-walled Polythene tube was inserted to join the two severed ends which were then separated by a furrow in the skin about $3 \mathrm{~cm}$ long. It was found that the considerable dorsoventral movement of the neck by the sheep resulted in a movement of this Polythene tube, with consequent constant traction on the two sutured ends of the trachea. If softer-walled tubing was inserted, movement of the head resulted in its collapse, and if no tube was inserted, a contraction of the 
wound occurred which tended to obliterate the lumen of the trachea. The sheep was destroyed.

In the remaining seven sheep a tracheostomy was made. The sheep was anaesthetized with Nembutal (Abbott Laboratories Ltd) and placed on the operating table. To prevent possible drainage of blood into the lungs or of regurgitated rumen contents into the trachea, the rear of the animal was elevated. A mid-line incision $3 \mathrm{~cm}$ long
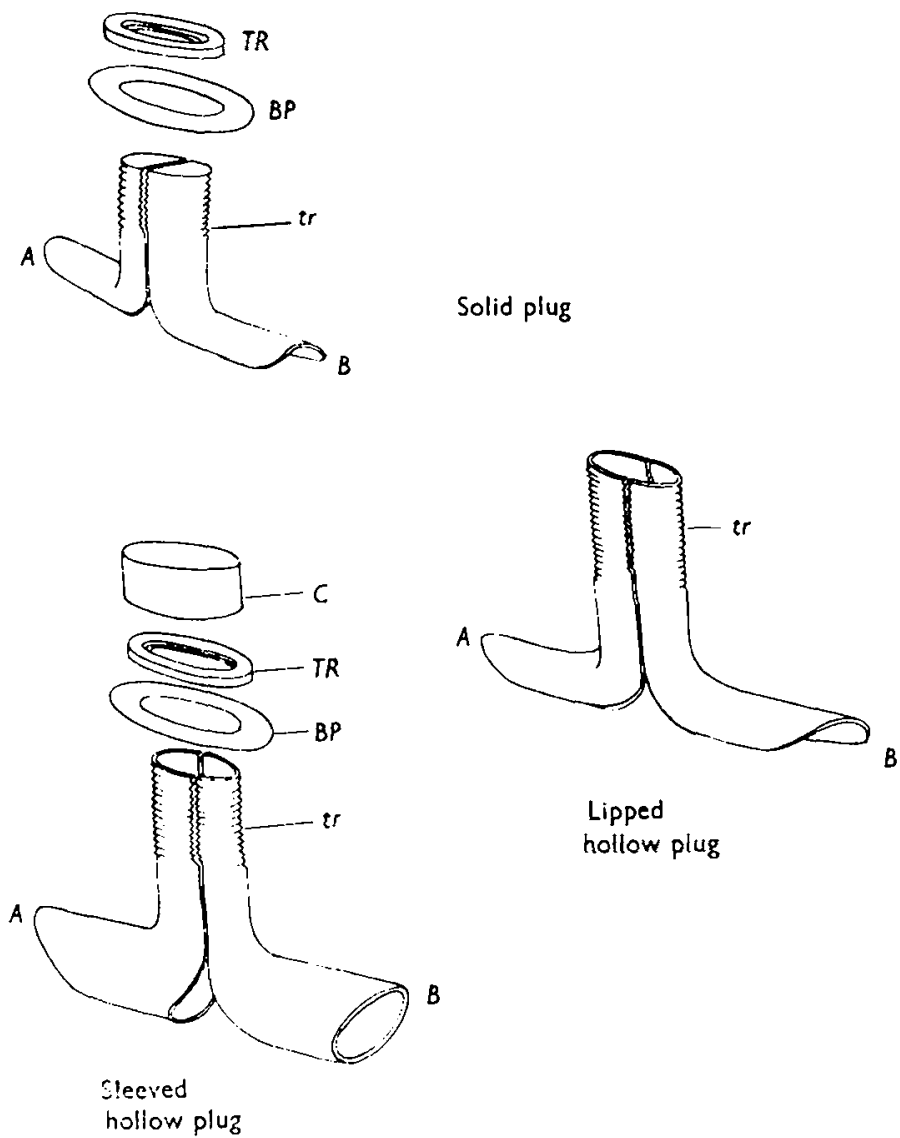

Lipped

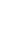


plug was removed and a hollow plug of Perspex inserted. These hollow plugs were of two types, as shown in Fig. I. One, the lipped type, consisted of a hollow threaded tube with two small lips and the other, the sleeved type, consisted of a hollow threaded tube to which was cemented a short tube of thin Perspex. The threaded tubes of both plugs were split into two to facilitate their insertion. With both types of plug a cap was screwed on to the threaded tube when the sheep was not on experiment so that breathing took place through the nose and mouth.

Maintenance of tracheostomized sheep. The sheep were anaesthetized at about 2-weekly intervals to remove the plug to clean or replace it. Considerable difficulties were encountered in ensuring that the trachea remained fully patent over several months. Evidently Cresswell \& Harris (1961) encountered similar difficulties. Two types of closure of the trachea were encountered. In the first, the trachea tended to collapse laterally with oedematous swelling, particularly in those sheep in which the trachea had a small internal diameter. This danger was accentuated by the use of lipped plugs and obviated by the use of sleeved plugs. In the second, callus formation occurred at the point where the leading edge of the internal lip or internal sleeve was in contact with the tracheal wall. In addition, some sheep could not easily cough mucus past the internal sleeves. This mucus tended to harden on the internal wall of the sleeve, thus blocking its lumen. Except in those instances reported in the case histories below when distress was evident immediately after feeding necessitating the fitting of new types of plug, the behaviour of the sheep was perfectly normal in all respects.

\section{Individual histories}

Sheep $A x$. A solid plug was fitted to this Cheviot sheep, collections of expired gas being made by insertion of a cuffed tracheal tube into the caudal trachea after removal of the plug. Lateral closure of the trachea with much swelling of the tracheal wall occurred after 50 days, when the sheep was destroyed.

Sheep Ct. A lipped hollow plug was fitted 17 days after the operation to this Blackface sheep. Partial closure through collapse occurred on the 84th day, when a sleeved plug was fitted into the cranial end of the trachea. A completely sleeved plug was fitted on the 13 rst day, but internal growth caused partial closure of the caudal part of the trachea and the sheep was destroyed on the 169 th day after the operation.

Sheep Cs. A lipped hollow plug was fitted on the $I 7$ th day after operation in this Cheviot sheep. It was replaced by a sleeved plug on the $79^{\text {th }}$ day since some signs of collapse of the trachea were noted. This plug was finally replaced by a complete sleeve (both caudal and cranial to the fistula) on the $3^{18 \text { th }}$ postoperative day. Internal callus formation occurred in the cranial part of the trachea and the sheep was killed on the 36 rst postoperative day.

Sheep $Z k$. A lipped hollow plug was fitted to this Blackface sheep on the $\mathrm{r}_{4}$ th postoperative day. A completely sleeved cannula was fitted on the 62 nd day. Growth of an inoperable callus with partial closure of the trachea necessitated the sheep's destruction on the i 8 th postoperative day.

Sheep $Y l$. This Down cross was fitted with a lipped plug on the $14^{\text {th }}$ postoperative 
day and the anterior part of the trachea with a sleeved plug on the 92nd day. On the 165th day both caudal and cranial parts of the trachea were sleeved. Callus formation on the wall of the cranial part of the trachea necessitated the sheep's slaughter on the $274^{\text {th }}$ postoperative day.

Sheep Se. This Cheviot sheep was fitted on the it th postoperative day with a lipped plug which in turn fitted into a short $\left(2 \frac{1}{2} \mathrm{~cm}\right)$ segment of Polythene tube which was inserted into the trachea. This device, used to prevent the initial lateral collapse of the trachea, was not successful and a complete sleeved cannula was fitted on the 47 th day. Growth of a callus in the cranial part of the trachea necessitated the sheep's slaughter on the I 8 2nd postoperative day.

Sheep $D l$. This Blackface sheep was initially treated in precisely the same way as sheep Se above. Respiratory distress due to oedematous swelling of the trachea developed on the $39^{\text {th }}$ day. Cannulation with a sleeved plug was not successful and the sheep died under anaesthesia when a further attempt at repair was made.

\section{Collection of expired air}

The method used to obtain expired air from the tracheostomized sheep was similar to that described by Webster \& Cresswell (1957) and by Cresswell (196r) in that an inflatable balloon was introduced into the upper trachea through the hollow plug so that all inspired and expired air was diverted through the hollow plug. The plug was connected by a short ( 8 in.) length of non-collapsible tubing (Siebe Gorman Co. Ltd) to a two-way mica valve assembly of the type used in studies with man (ZentralWerkstatt Göttingen G.m.b.H., Göttingen, Germany). The expiratory side of this valve was then connected with large Douglas bags measuring $42 \times 42 \times 12$ in., which were manufactured from butyl rubber (J. G. Franklin and Sons Ltd) to our specification. A two-way, I in. bore aluminium stop-cock (Siebe Gorman Co. Ltd) placed between the expiratory valve and the bag allowed the expired air to be directed to the Douglas bag when required. The volume of the bag allowed collections of expired air to be made for periods of up to $30 \mathrm{~min}$. For the normal amount of gas collected the pressure exerted by the Douglas bags, that is the resistance they caused to breathing, was $2 \mathrm{~mm}$ water. This resistance was very constant throughout the collection period; indeed a pressure rise was only detected when the bags were obviously full and distended.

\section{Measurement of expired air volume and respiratory metabolism}

The Douglas bags were emptied by means of a vacuum pump (W. Edwards and Co. (London) Ltd). The outflow from the vacuum pump was led through $9 \mathrm{ft}$ of rubber tubing to a precision wet-gas meter (Parkinson and Cowan Industrial Products). This length of tubing was found adequate for sufficient cooling of the air, which was heated slightly in its passage through the pump, to prevent a temperature rise in the wet-gas meter. The use of a vacuum pump ensured a standard and quantitative emptying of the bags in each experiment and a constant rate of air flow through the meter. The calibration of the meter was checked by passing through it weighed amounts of nitrogen and air in known volumes as measured in large spirometers. A sample of 
the air was taken from the outflow of the wet-gas meter, due precaution being taken to allow for wash-out time and for any equilibration of the $\mathrm{CO}_{2}$ in the air stream with the water in the meter. This sample was dried by passing it over $\mathrm{CaCl}_{2}$ and analysed for $\mathrm{O}_{2}$ with a paramagnetic oxygen analyser and for $\mathrm{CO}_{2}$ by an analyser that determined thermal conductivity. $\mathrm{CH}_{4}$ was determined from the $\mathrm{CO}_{2}$ formed after its combustion over palladium. The analyser (Cambridge Instrument Co. Ltd) was checked daily by analysis of outdoor air, pure $\mathrm{N}_{2}$ and two standard mixtures of $\mathrm{O}_{2}$, $\mathrm{N}_{2}, \mathrm{CO}_{2}$ and $\mathrm{CH}_{4}$ and also by analysis of single samples of expired air by the Haldane method. Each complete analysis took $7 \mathrm{~min}$ and forty or more determinations could be made each day.

Calculations of inspired air volumes were made on the assumption that the volume of $\mathrm{N}_{2}$ inspired was the same as that expired. $\mathrm{O}_{2}$ consumption and $\mathrm{CH}_{4}$ production were computed from the differences between inspired and expired amounts.

Testing the method. The whole assembly was tested for leaks by comparing the volume of $\mathrm{N}_{2}$ inspired from one Douglas bag with that expired into another. A large volume of air of known $\mathrm{N}_{2}$ content was measured into a Douglas bag with a wet-gas meter. The inspiratory valve of the assembly was connected with this bag and the sheep allowed to expire air into a second bag. When the inspiratory bag was almost empty, the residual volume of air was measured with the wet-gas meter to give the inspired volume of $\mathrm{N}_{2}$. Measurement of the volume and $\mathrm{N}_{2}$ content of the air expired by the sheep gave the volume of $\mathrm{N}_{2}$ expired. In five such tests the recovery of $\mathrm{N}_{2}$ was $99 \cdot 0 \pm 1 \cdot 1 \%$.

The introduction of a balloon into the upper trachea, and the diversion of expired air into a bag involved considerable interference with the sheep. To test the extent to which measurements of consumed $\mathrm{O}_{2}$ made with Douglas bags agreed with the amounts consumed when the animal was not restrained, comparisons were made of the $\mathrm{O}_{2}$ consumption of the tracheostomized sheep given constant rations and kept in a respiration chamber, and $\mathrm{O}_{2}$ consumption determined from the Douglas bag measurements. Two series of such tests were made.

In the first series of tests, sheep $C t$ and sheep $C s$ were given $800 \mathrm{~g}$ dried grass ( $16.99 \%$ protein) and $200 \mathrm{~g}$ crushed oats in two meals at 5.30 am and $4.00 \mathrm{pm}$ each day. On 5 consecutive days each sheep was confined in a respiration chamber and the consumption of $\mathrm{O}_{2}$ and production of $\mathrm{CO}_{2}$ and $\mathrm{CH}_{4}$ were determined over $24 \mathrm{~h}$. In addition, $\mathrm{O}_{2}$ consumption and $\mathrm{CH}_{4}$ production, but not $\mathrm{CO}_{2}$ production, were determined hourly from Io am to $6 \mathrm{pm}$, making eight determinations on each day. The times spent standing and lying were also measured in each hour. When these determinations were complete, measurements of $\mathrm{O}_{2}$ consumption, $\mathrm{CO}_{2}$ and $\mathrm{CH}_{4}$ production were made by the Douglas bag method. Thirty-two determinations were made with each sheep between 10 am and $4 \mathrm{pm}$, measurements being spread over 6 days with sheep $C t$ and over 3 days with sheep $C s$. In addition, with sheep $C t$ two series of measurements of metabolism were made with Douglas bags to cover the hour before feeding and the hour after feeding.

In the second series of tests, sheep $C s, S e$ and $Y l$ were each given three different amounts of a diet of dried grass and oats in equal proportions. The amounts of the 
mixture given to sheep Cs were $900, \mathrm{I} 35^{\circ}$ and I $800 \mathrm{~g} /$ day, to sheep $S e 450,900$ and $135^{\circ} \mathrm{g} /$ day and to sheep $\mathrm{Yl} 45^{\circ}, \mathrm{I} 35^{\circ}$ and $\mathrm{I} 800 \mathrm{~g} /$ day. After a preliminary period of 14 days on each ration each sheep was confined in the respiration chamber for 3 days and on each day $\mathrm{O}_{2}$ consumption, $\mathrm{CO}_{2}$ and $\mathrm{CH}_{4}$ production were measured for three consecutive periods of $3 \mathrm{~h}$ from $9 \mathrm{am}$ to $6 \mathrm{pm}$ and for the night period of $15 \mathrm{~h}$ each day. The sheep were given their rations in two meals at $6 \mathrm{am}$ and $6 \mathrm{pm}$. When the experiments in the respiration chamber were complete, measurements of the respiratory exchange were made by the Douglas bag method between the hours of 9 am and $5 \mathrm{pm}$.

Respiration chamber experiments. The chamber described by Wainman \& Blaxter (1958) was used.

\section{RESULTS}

\section{Effect of standing on $\mathrm{O}_{2}$ consumption}

When in the respiration chamber the sheep, being unrestrained, could lie at will and usually did so for long periods. When the Douglas bag technique was used they could lie if they wished but they invariably stood. Pullar's (1962) observation that standing can increase heat emissions by up to $70 \%$ suggests that in any comparison between chamber and Douglas bag measurements account should be taken of any increase in rate of $\mathrm{O}_{2}$ consumption during standing.

Analysis of covariance of the results of the two series of experiments in the respiration chamber was made and the regression of hourly $\mathrm{O}_{2}$ consumption on standing time was computed from the residual sum of squares after components of variation attributable to ration, time of day, days of experiment and the interaction ration $\times$ time of day had been removed. The results are given in Table $\mathbf{I}$.

The results showed that standing resulted in an increase in $\mathrm{O}_{2}$ consumption in both series of experiments but in neither was the effect significant statistically. The value of I $1 . \mathrm{O}_{2} / \mathrm{h}$, corresponding to about $5.0 \mathrm{kcal} / \mathrm{h}$ or $\mathrm{I} \cdot 7 \mathrm{kcal} / \mathrm{kg}$ body-weight $24 \mathrm{~h}$ is in agreement with observations of Hall \& Brody (r933) that the increase in metabolism as measured from $\mathrm{O}_{2}$ consumption in cattle is $2 \cdot 1 \mathrm{kcal} / \mathrm{kg}$ body-weight $24 \mathrm{~h}$. It is much smaller than the increased heat output noted by Pullar (1962) and, as it was not statistically significant, the effect of standing has been ignored in subsequent calculations.

\section{Comparison of respiratory measurements and chamber measurements in the first series of experiments}

In Table 2, a comparison is made between the measurements made over $24 \mathrm{~h}$ periods in the respiration chamber, those made over $\mathrm{I} h$ periods between meals in the respiration chamber and those made by the Douglas bag technique.

The results show that the Douglas bag method for determining $\mathrm{O}_{2}$ consumption gave results that agreed with those determined by hourly measurements in the chamber, the means being $16 \cdot 23$ and $16 \cdot 151 . / \mathrm{h}$ respectively. The values were very close to those determined over $24 \mathrm{~h}$ in the respiration chamber. The $\mathrm{CO}_{2}$ production determined by Douglas bag was 4.01 . lower in sheep $C t$ and 4.21 . lower in sheep Cs than the $1 . / \mathrm{h}$ values computed from the $24 \mathrm{~h}$ respiration chamber experiments. 
$\mathrm{CH}_{4}$ production measured by Douglas bag was very small and only about one-tenth of that obtained by hourly measurements in the chamber. Hourly measurements of $\mathrm{CH}_{4}$ production made during the intervals between meals were lower than the mean values computed from the $24 \mathrm{~h}$ measurement of $\mathrm{CH}_{4}$ production, which includes the effects of two meals.

Table I. Pooled regression of oxygen consumption of sheep $(l . / h$ on standing time $(h))$

$\begin{array}{lccc}\text { Series of experiments } & \text { df } & \begin{array}{c}\text { Increase in } \\ \mathrm{O}_{2} \text { consumption } \\ \text { on standing }\end{array} & \begin{array}{c}\text { Mean } \mathrm{O}_{2} \\ \text { consumption }\end{array} \\ \text { 1st }(\mathrm{I} \mathrm{h} \text { measurements) } & 53 & 0.79 \pm 0.85 & 15.26 \\ \text { 2nd }(3 \mathrm{~h} \text { measurements) } & 36 & 1.07 \pm \mathrm{r} \cdot 34 & 17.31\end{array}$

- Results of an additional two experiments in which hourly collections were made have been included together with those of the two experiments included in series $\mathrm{I}$.

Table 2. Comparison of the hourly oxygen consumption and carbon dioxide and methane production of two sheep measured in three ways

\begin{tabular}{|c|c|c|c|c|c|c|c|}
\hline & & & & Method of $\mathrm{m}$ & measurement & & \\
\hline & & Res & piration chan & mber measure & ements & & \\
\hline & & Durin & g $24 h$ & Durin & $\mathrm{ng}$ i h & measur & rements \\
\hline Measurement & Shcep & $\begin{array}{c}\text { No. of } \\
\text { observations }\end{array}$ & $\begin{array}{r}\text { Value } \\
(1 . / \mathrm{h})\end{array}$ & $\begin{array}{c}\text { No. of } \\
\text { observations }\end{array}$ & $\begin{array}{l}\text { Value } \\
\qquad(1 . / \mathrm{h})\end{array}$ & $\begin{array}{c}\text { No. of } \\
\text { observations }\end{array}$ & $\begin{array}{r}\text { Value } \\
(1 . / \mathrm{h})\end{array}$ \\
\hline $\mathrm{O}_{2}$ consumption & $\begin{array}{l}C t \\
C s\end{array}$ & $\begin{array}{l}10 \\
10\end{array}$ & $\begin{array}{l}16.08 \pm 0.18 \\
16.73 \pm 0.09\end{array}$ & $\begin{array}{l}30 \\
30\end{array}$ & $\begin{array}{l}16.33 \pm 0.22 \\
15.92 \pm 0.26\end{array}$ & $\begin{array}{l}27 \\
27\end{array}$ & $\begin{array}{l}16.09 \pm 0.29 \\
16.37 \pm 0.26\end{array}$ \\
\hline $\mathrm{CO}_{2}$ production & $\begin{array}{l}C t \\
C s\end{array}$ & $\begin{array}{l}\text { ro } \\
\text { Io }\end{array}$ & $\begin{array}{l}16.89 \pm 0.19 \\
17.56 \pm 0.08\end{array}$ & - & - & $\begin{array}{l}27 \\
27\end{array}$ & $\begin{array}{l}12.89 \pm 0.26 \\
13.36 \pm 0.25\end{array}$ \\
\hline $\mathrm{CH}_{4}$ production & $\begin{array}{l}C t \\
C s\end{array}$ & $\begin{array}{l}10 \\
10\end{array}$ & $\begin{array}{l}1.47 \pm 0.03 \\
1.36 \pm 0.02\end{array}$ & $\begin{array}{l}30 \\
30\end{array}$ & $\begin{array}{l}1 \cdot 29 \\
1 \cdot 20\end{array}$ & $\begin{array}{l}27 \\
27\end{array}$ & $\begin{array}{l}0.11 \pm 0.01 \\
0.16 \pm 0.02\end{array}$ \\
\hline
\end{tabular}

In sheep $C t$ probably about 4.01 . of the $\mathrm{CO}_{2}$ and $\mathrm{I} \cdot 2 \mathrm{I}$. of the $\mathrm{CH}_{4}$ produced were not collected when tracheal gas was collected for an hour. In sheep $C s$, probably about 4.21 . of the $\mathrm{CO}_{2}$ and $1 \cdot 01$. of the $\mathrm{CH}_{4}$ produced were not collected. The inference is that these volumes were lost by belching, but the possibility that small amounts were lost through the skin and anus is not discounted. Belching, however, was obviously the most important source of these large volumes of gas. When the caps of the hollow plugs were removed, belching could readily be detected by an amplification of its characteristic noise by the upper trachea. Dougherty (196I) has shown that when sheep belch the glottis remains open and belched gas enters the respiratory passages. When the cap is removed from the hollow plug, the belched gases emerge and can be smelled. There is rarely, if ever, a similar smell in the air expired normally from the nostrils of intact sheep or of sheep with closed tracheostomies.

The results show that the use of tracheostomized sheep gives results for $\mathrm{O}_{2}$ consumption in agreement with those determined without restraint or interference but that $\mathrm{CO}_{2}$ and $\mathrm{CH}_{4}$ production are underestimated. 


\section{Comparison of respiratory measurements and chamber measurements in the second series of experiments}

The second series of experiments was made to find whether belching was affected by the feeding level of the sheep, and whether an estimate of the respiratory quotient could be obtained by correcting the values found for $\mathrm{CO}_{2}$ production and $\mathrm{CH}_{4}$ production by the Douglas bag method for the amounts presumed to be lost in the belch.

Table 3. Comparison of oxygen consumption and carbon dioxide and methane production of sheep given different rations determined in two ways

\begin{tabular}{|c|c|c|c|c|}
\hline Measurement & $\begin{array}{l}\text { Ration } \\
\text { (g/day) }\end{array}$ & Sheep & $\begin{array}{c}\begin{array}{c}\text { Respiration } \\
\text { chamber }\end{array} \\
\text { measurements* } \\
(1 . / \mathrm{h})\end{array}$ & $\begin{array}{c}\text { Douglas bag } \\
\text { measurements } \dagger \\
(1 . / \mathrm{h})\end{array}$ \\
\hline \multirow[t]{4}{*}{$\mathrm{O}_{2}$ consumption } & 450 & $\begin{array}{l}Y l \\
\mathrm{Se}\end{array}$ & $\begin{array}{l}14.34 \pm 0.35 \\
14.96 \pm 0.32\end{array}$ & $\begin{array}{l}14.52 \pm 0.15 \\
15.06 \pm 0.17\end{array}$ \\
\hline & 900 & $\begin{array}{l}\mathrm{Se} \\
\mathrm{Cs}\end{array}$ & $\begin{array}{l}15.17 \pm 0.32 \\
14.07 \pm 0.24\end{array}$ & $\begin{array}{l}15.11 \pm 0.26 \\
13.59 \pm 0.19\end{array}$ \\
\hline & I $35^{\circ}$ & $\begin{array}{l}Y l \\
\mathrm{Cs} \\
\mathrm{Se}\end{array}$ & $\begin{array}{l}18.95 \pm 0.35 \\
17.90 \pm 0.24 \\
17.38 \pm 0.32\end{array}$ & $\begin{array}{l}19.10 \pm 0.27 \\
18.05 \pm 0.13 \\
17.99 \pm 0.26\end{array}$ \\
\hline & 1800 & $\begin{array}{l}Y l \\
C s\end{array}$ & $\begin{array}{l}22 \cdot 19 \pm 0.35 \\
20.79 \pm 0.24\end{array}$ & $\begin{array}{l}22.42 \pm 0.30 \\
21.08 \pm 0.22\end{array}$ \\
\hline \multirow[t]{4}{*}{$\mathrm{CO}_{2}$ production } & $45^{\circ}$ & $\begin{array}{l}Y l \\
S e\end{array}$ & $\begin{array}{l}12.06 \pm 0.34 \\
13.20 \pm 0.38\end{array}$ & $\begin{array}{l}12.34 \pm 0.17 \\
13.04 \pm 0.16\end{array}$ \\
\hline & 900 & $\begin{array}{l}\text { Se } \\
\text { Cs }\end{array}$ & $\begin{array}{l}14.94 \pm 0.38 \\
13.94 \pm 0.29\end{array}$ & $\begin{array}{l}14.87 \pm 0.22 \\
13.55 \pm 0.23\end{array}$ \\
\hline & 1350 & $\begin{array}{l}Y l \\
\mathrm{Cs} \\
\mathrm{Se}\end{array}$ & $\begin{array}{l}19.47 \pm 0.34 \\
18.56 \pm 0.29 \\
18.11 \pm 0.38\end{array}$ & $\begin{array}{l}18.02 \pm 0.29 \\
17.03 \pm 0.28 \\
17.59 \pm 0.27\end{array}$ \\
\hline & 1800 & $\begin{array}{l}Y l \\
C s\end{array}$ & $\begin{array}{l}24.06 \pm 0.34 \\
21.59 \pm 0.29\end{array}$ & $\begin{array}{l}21 \cdot 87 \pm 0.29 \\
20.90 \pm 0.33\end{array}$ \\
\hline \multirow[t]{4}{*}{$\mathrm{CH}_{4}$ production } & $45^{\circ}$ & $\begin{array}{l}Y l \\
S e\end{array}$ & $\begin{array}{l}0.66 \pm 0.095 \\
0.80 \pm 0.056\end{array}$ & $\begin{array}{l}0.21 \pm 0.0081 \\
0.13 \pm 0.0077\end{array}$ \\
\hline & 900 & $\begin{array}{l}\text { Se } \\
\text { Cs }\end{array}$ & $\begin{array}{l}1.23 \pm 0.056 \\
1.15 \pm 0.104\end{array}$ & $\begin{array}{l}0.21 \pm 0.011 \\
0.35 \pm 0.03\end{array}$ \\
\hline & $135^{\circ}$ & $\begin{array}{l}Y l \\
\mathrm{Cs} \\
\mathrm{Se}\end{array}$ & $\begin{array}{l}r \cdot 64 \pm 0.095 \\
r .43 \pm 0.104 \\
r .58 \pm 0.056\end{array}$ & $\begin{array}{l}0.16 \pm 0.013 \\
0.11 \pm 0.02 \\
0.40 \pm 0.0098\end{array}$ \\
\hline & 1800 & $\begin{array}{l}Y l \\
C s\end{array}$ & $\begin{array}{l}2.04 \pm 0.095 \\
1.57 \pm 0.104\end{array}$ & $\begin{array}{l}0.44 \pm 0.11 \\
0.36 \pm 0.04\end{array}$ \\
\hline
\end{tabular}

- Mean values with their standard errors for nine observations.

+ Mean values with their standard errors for sixteen observations.

The results of the nine experiments are given in Table 3 . The mean $\mathrm{O}_{2}$ consumption measured in the chamber was 0.021 ./h lower than that measured by Douglas bag. This systematic difference was not significant statistically and, in any event, it is numerically negligible compared with the mean consumption of $17.3 \mathrm{l} / \mathrm{h}$. As in the first series of experiments, less $\mathrm{CO}_{2}$ and less $\mathrm{CH}_{4}$ were collected in the Douglas bags than were produced in the chamber.

The amount of $\mathrm{CH}_{4}$ produced when a sheep was in the chamber can be taken as a 
convenient index of the amount of fermentation that occurred, and in Fig. 2 the amount of $\mathrm{CH}_{4}$ belched (estimated as the difference between the amount produced in the chamber and that collected in the Douglas bag) has been plotted against $\mathrm{CH}_{4}$ production. Fig. 2 includes also the results of two observations made in the first series of experiments.

The regression of $\mathrm{CH}_{4}$ belched on $\mathrm{CH}_{4}$ produced was:

$$
\text { belched } \mathrm{CH}_{4}(1 . / \mathrm{h})=0.833 \mathrm{CH}_{4}(1 . / \mathrm{h}) \text { produced }-0.03 \text {. }
$$

The regression was highly significant statistically $(P<0.00 \mathrm{I})$ and the residual standard deviation was $\pm 0.10 \mathrm{l} / \mathrm{h}$. In Fig. 3 the $\mathrm{CO}_{2}$ presumed to be belched has

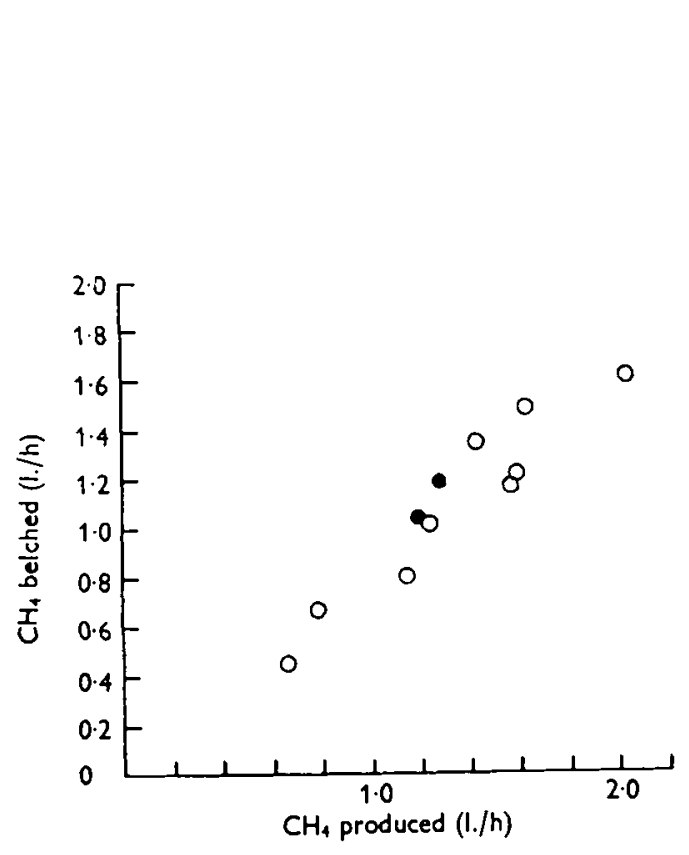

Fig. 2

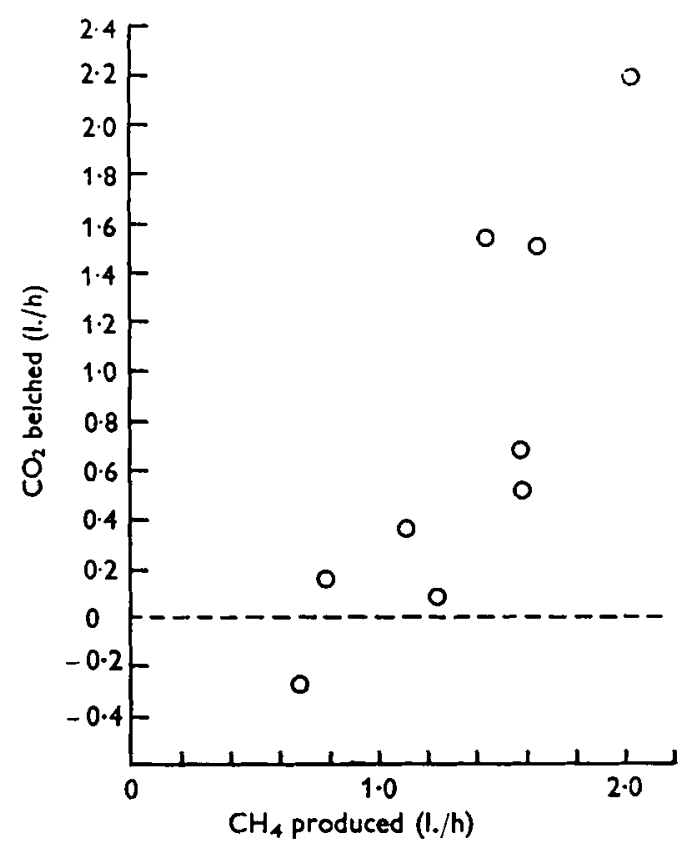

Fig. 3

Fig. 2. Volume of $\mathrm{CH}_{4}$ not accounted for, and presumed to have been belched, when the pulmonary exchange of sheep was measured and volume of $\mathrm{CH}_{4}$ produced, which is an index of the amount of fermentation. $\bullet$, values from the first; 0 , values from the second series of experiments.

Fig. 3. Volume of $\mathrm{CO}_{2}$ not accounted for, and presumed to have been belched, when the pulmonary exchange of sheep was measured and volume of $\mathrm{CH}_{6}$ produced, which is an index of the amount of fermentation.

been plotted against the $\mathrm{CH}_{4}$ production. No results for the first series of experiments are available in this instance. The regression of $\mathrm{CO}_{2}$ belched on $\mathrm{CH}_{4}$ produced was:

$$
\text { belched } \mathrm{CO}_{2}(1 . / \mathrm{h})=1 \cdot 579 \mathrm{CH}_{4}(1 . / \mathrm{h}) \text { produced }-1 \cdot 38 \text {. }
$$

This regression was significant $(0.00 \mathrm{I}<P<0.0 \mathrm{I})$ and the residual standard deviation was $\pm 0.42 \mathrm{l} . / \mathrm{h}$.

Equation (I) shows that $\mathrm{CH}_{4}$ loss on belching was proportional to $\mathrm{CH}_{4}$ production since the intercept term $(-0.03 \mathrm{l} . / \mathrm{h})$ was not significantly different from zero, and that about $83 \%$ of the $\mathrm{CH}_{4}$ produced was lost by belching irrespective of the feeding 
level. Conversely $17 \%$ of the $\mathrm{CH}_{4}$ was absorbed into the blood and excreted by the lungs. With $\mathrm{CO}_{2}$, however, equation (2) shows that little $\mathrm{CO}_{2}$ was belched until $\mathrm{CH}_{4}$ production exceeded $0.87 \mathrm{l} / \mathrm{h}$ and then loss of $\mathrm{CO}_{2}$ on belching increased very rapidly. When $\mathrm{CH}_{4}$ production was $\mathrm{r} \mathrm{l} / \mathrm{h}$ the belched gas contained $0.57 \mathrm{l} . \mathrm{CH}_{4} / \mathrm{h}$ and $0.201 . \mathrm{CO}_{2} / \mathrm{h}$, that is nearly three times as much $\mathrm{CH}_{4}$ as $\mathrm{CO}_{2}$ was belched. When $\mathrm{CH}_{4}$ production was $2.5 \mathrm{l} . / \mathrm{h}, \mathrm{I} \cdot 83 \mathrm{l} . \mathrm{CH}_{4} / \mathrm{h}$ were lost and $2.561 . \mathrm{CO}_{2} / \mathrm{h}$, that is considerably more $\mathrm{CO}_{2}$ than $\mathrm{CH}_{4}$ was belched.

\section{$\mathrm{O}_{2}$ consumption during eating}

In the first series of experiments in the respiration chamber, $\mathrm{O}_{2}$ consumption and $\mathrm{CH}_{4}$ production were measured during feeding and for a period after feeding. The mean results for each sheep showed that, from the $5^{\text {th }}$ to the $\mathrm{i}$ th $\mathrm{h}$ after the morning meal, $\mathrm{O}_{2}$ consumption/h varied very little about the mean values given in Table 2 . $\mathrm{CH}_{4}$ production, however, tended to fall. During the ist $\mathrm{h}$ after feeding, the $\mathrm{O}_{2}$ consumption of sheep $C t$ increased from a mean value of 15.9 to $21 \cdot 3 \mathrm{l} / \mathrm{h}$, or by $34 \%$.

Table 4. Mean rates $(l . / h)$ of oxygen consumption and of carbon dioxide and methane production in relation to time of feeding of three sheep given four rations

\begin{tabular}{|c|c|c|c|c|c|}
\hline Measurement & $\begin{array}{c}\text { Ration } \\
\text { (g/day) }\end{array}$ & $\begin{array}{c}3-6 h \\
\text { after food }\end{array}$ & $\begin{array}{c}6-9 \mathrm{~h} \\
\text { after food }\end{array}$ & $\begin{array}{c}9-12 \mathrm{~h} \\
\text { after food }\end{array}$ & $\begin{array}{l}\text { I } 5 \text { h night } \\
\text { interval, } \\
\text { including } \\
\text { two meals }\end{array}$ \\
\hline \multirow[t]{4}{*}{$\mathrm{O}_{2}$ consumption } & 450 & 13.4 & 14.5 & $14 \cdot 2$ & 13.0 \\
\hline & 900 & 14.1 & 14.0 & $15 \cdot 8$ & 14.9 \\
\hline & 1350 & $17 \cdot 3$ & $18 \cdot 1$ & 18.8 & I 8.8 \\
\hline & 1800 & $2 \mathrm{I} \cdot 6$ & $21 \cdot 4$ & $21 \cdot 6$ & $23 \cdot 3$ \\
\hline \multirow[t]{4}{*}{$\mathrm{CO}_{2}$ production } & 450 & $12 \cdot 3$ & $12 \cdot 6$ & 13.0 & II 9 \\
\hline & 900 & 14.9 & 14.2 & $14 \cdot 2$ & 15.7 \\
\hline & 1350 & $19 \cdot 0$ & $18 \cdot 7$ & $18 \cdot 4$ & $21 \cdot 0$ \\
\hline & 1800 & $23 \cdot 7$ & $22 \cdot 2$ & $22 \cdot 5$ & $26 \cdot 5$ \\
\hline \multirow[t]{4}{*}{$\mathrm{CH}_{4}$ production } & 450 & 0.88 & 0.88 & 0.42 & 0.71 \\
\hline & 900 & $I \cdot 40$ & $I \cdot 40$ & 0.76 & $I \cdot 41$ \\
\hline & 1350 & $1 \cdot 92$ & $x \cdot 76$ & $1 \cdot 03$ & $1 \cdot 77$ \\
\hline & 1800 & $2 \cdot 25$ & $1 \cdot 99$ & $I \cdot 16$ & $2 \cdot 03$ \\
\hline
\end{tabular}

The $\mathrm{O}_{2}$ consumption of sheep Cs increased from a mean value of 16.3 to $24.91 . / \mathrm{h}$ or by $52 \%$. The meal was completely consumed within $30 \mathrm{~min}$ and in the subsequent hour $\mathrm{O}_{2}$ consumption had fallen to initial levels in sheep $C t$ but was still elevated in sheep $C s$. $\mathrm{CH}_{4}$ production increased during the $\mathrm{Ist} h$ of feeding in both sheep, and with sheep $\mathrm{Cs}$ a rise was still noticeable in the 2 nd $\mathrm{h}$. The increase in $\mathrm{CH}_{4}$ production in the Ist $\mathrm{h}$ after feeding compared with that in the $\mathrm{I} I$ th was about $60 \%$.

In the second series of experiments, in addition to the three $3 \mathrm{~h}$ measurements of metabolism made during the day, metabolism was also measurcd for the remaining I $5 \mathrm{~h}$ of the day. This 'night' period included two meals given at $12 \mathrm{~h}$ intervals. Table 4 shows the mean hourly rates of the gaseous exchange for the three $3 \mathrm{~h}$ periods and for the $15 \mathrm{~h}$ period when each of the four rations was given. There was no evidence of any decline in $\mathrm{O}_{2}$ consumption or $\mathrm{CO}_{2}$ production from the 3 rd $\mathrm{h}$ after feeding until the 12 th $\mathrm{h}$; indeed in some instances a slight rise occurred in the last period. $\mathrm{CH}_{4}$ 
production, however, fell from one $3 \mathrm{~h}$ period to the next. The results for $\mathrm{O}_{2}$ were in agreement with those obtained in the first series of experiments.

An estimate can be made of the $\mathrm{O}_{2}$ consumption and $\mathrm{CO}_{2}$ and $\mathrm{CH}_{4}$ production associated with the two meals by making the assumption that the metabolism during the $9 \mathrm{~h}$ before the morning meal was the same as that for the $9 \mathrm{~h}$ before the evening meal. The mean hourly consumption of $\mathrm{O}_{2}$ during the $3 \mathrm{~h}$ in which a meal occurred was thus

$\frac{\mathrm{I}}{2}\left(\begin{array}{c}5 \times \text { hourly } \mathrm{O}_{2} \text { consumption during } \\ \text { the } 15 \mathrm{~h} \text { night interval }\end{array}-\begin{array}{c}3 \times \text { hourly } \mathrm{O}_{2} \text { consumption during } \\ \text { the } 9 \mathrm{~h} \text { day interval }\end{array}\right)$.

The results of such calculations are given in Table 5. They indicate that, with the lowest amount of food, the increase in metabolism during the $3 \mathrm{~h}$ following food was

Table 5. Estimated rates of oxygen consumption and of carbon dioxide and methane production, before and during meals, by three sheep given four rations

\begin{tabular}{|c|c|c|c|c|}
\hline Measurement & $\begin{array}{l}\text { Ration } \\
\text { (g/day) }\end{array}$ & $\begin{array}{c}\text { In } 9 \mathrm{~h} \\
\text { preceding } \\
\text { meal } \\
(1 . / \mathrm{h})\end{array}$ & $\begin{array}{c}\text { In } 3 \mathrm{~h} \\
\text { including } \\
\text { meal } \\
(1 . / \mathrm{h})\end{array}$ & $\begin{array}{c}\text { Estimated } \\
\text { increment } \\
\text { due to } \\
\text { feeding } \\
(1 . / \mathrm{h})\end{array}$ \\
\hline $\mathrm{O}_{2}$ consumption & $\begin{array}{r}450 \\
900 \\
1350 \\
1800\end{array}$ & $\begin{array}{l}14 \cdot 0 \\
14.6 \\
18 \cdot 1 \\
21 \cdot 5\end{array}$ & $\begin{array}{l}11 \cdot 5 \\
15 \cdot 3 \\
20 \cdot 0 \\
25 \cdot 9\end{array}$ & $\begin{array}{l}-2.5 \\
+0.7 \\
+1.9 \\
+4.4\end{array}$ \\
\hline $\mathrm{CO}_{2}$ production & $\begin{array}{r}450 \\
900 \\
1350 \\
1800\end{array}$ & $\begin{array}{l}12.6 \\
14.4 \\
18 \cdot 7 \\
22.8\end{array}$ & $\begin{array}{l}10.7 \\
17.7 \\
24.5 \\
32.1\end{array}$ & $\begin{array}{l}-1.9 \\
+3.3 \\
+5.8 \\
+9.3\end{array}$ \\
\hline $\mathrm{CH}_{4}$ production & $\begin{array}{r}45^{\circ} \\
900 \\
1350 \\
1800\end{array}$ & $\begin{array}{l}0.73 \\
1.19 \\
1.55 \\
1.80\end{array}$ & $\begin{array}{l}0 \cdot 64 \\
1 \cdot 74 \\
2 \cdot 10 \\
2 \cdot 36\end{array}$ & $\begin{array}{l}-0.09 \\
+0.55 \\
+0.55 \\
+0.56\end{array}$ \\
\hline
\end{tabular}

apparently negative. This is undoubtedly an artifact since when this submaintenance ration was given the sheep were particularly active during the day and the negative value suggests that metabolism during the corresponding $9 \mathrm{~h}$ of the night interval was grossly overestimated. The results with the rations of $900,135^{\circ}$ and $1800 \mathrm{~g}$ dried grass showed increases in $\mathrm{O}_{2}$ consumption and, more particularly, of $\mathrm{CO}_{2}$ production during the feeding period. The ratio of the increase in $\mathrm{CO}_{2}$ production to the increase in $\mathrm{O}_{2}$ consumption for these three rations exceeded $2 \cdot 0$ in all instances, suggesting very strongly that much of the $\mathrm{CO}_{2}$ arose from incomplete degradation of the food, that is in the fermentation process. The excess $\mathrm{CO}_{2}$ probably represents belched gas. The increase in $\mathrm{CH}_{4}$ production during the $3 \mathrm{~h}$ period containing a meal was constant at $0.551 . / \mathrm{h}$.

Experiments with sheep $C t$ were made to give further information on the effects of feeding. The Douglas bag method was used, and Fig. 4 shows the results obtained in one experiment. When food was brought into the room ro min before feeding, both $\mathrm{O}_{2}$ consumption and $\mathrm{CO}_{2}$ production increased. $\mathrm{O}_{2}$ consumption was maximal from 
the $5^{\text {th }}$ to the roth min after feeding when it was $67 \%$ higher than the values noted 20-30 min before feeding. $\mathrm{CO}_{2}$ production from the lungs at this time was $84 \%$ higher than initial values and the ratio of the increase in $\mathrm{CO}_{2}$ production to the

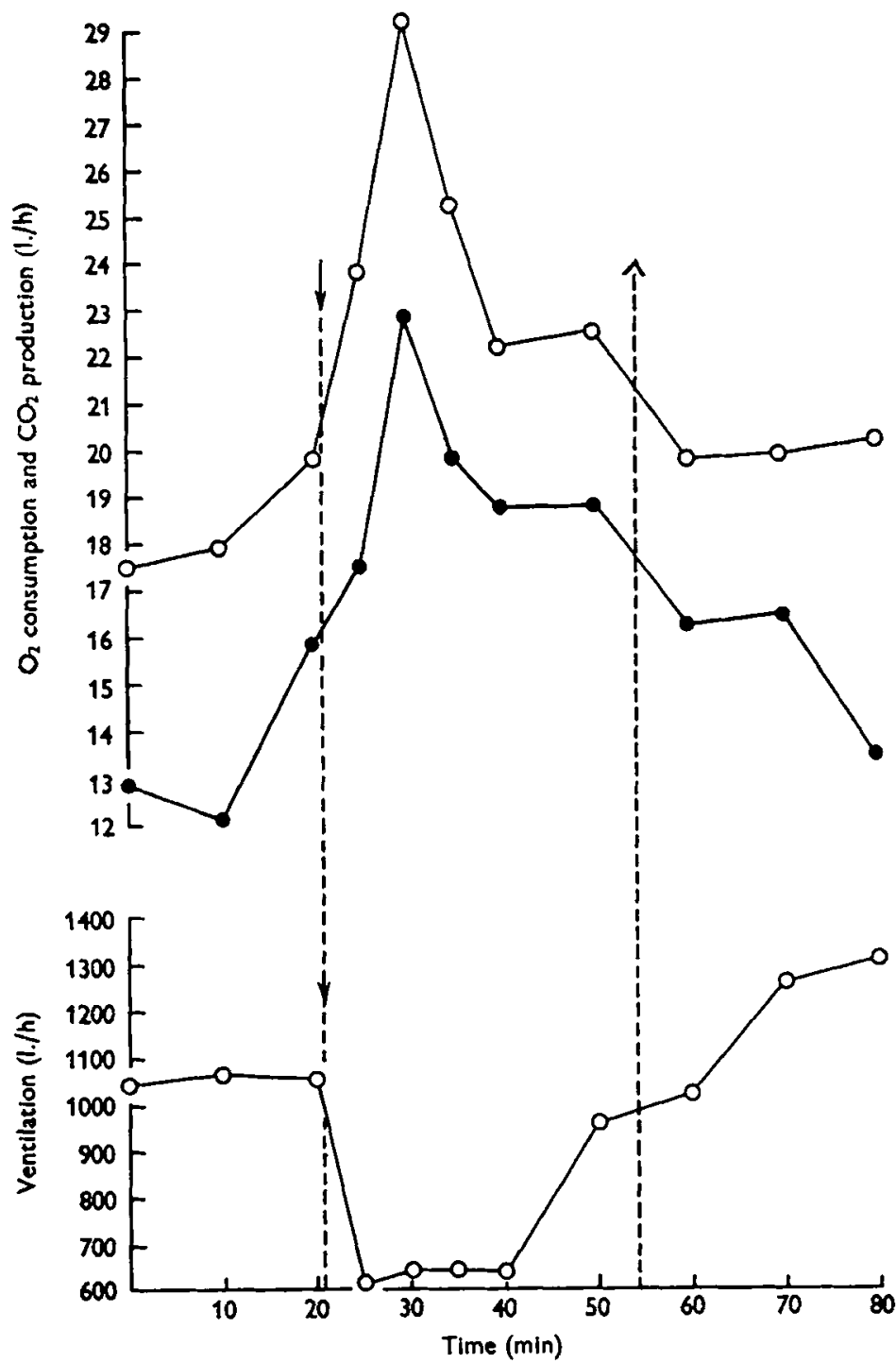

Fig. 4. Effect of a meal given at $\downarrow$ and finished at $\uparrow$ on $\mathrm{O}_{2}$ consumption and $\mathrm{CO}_{2}$ production (upper graph) and puimonary ventilation/h (lower graph) in sheep $C t$. Upper graph: $\mathrm{C}-\mathrm{O}, \mathrm{O}_{2}$ consumption;,$- \mathrm{CO}_{2}$ production.

increase in $\mathrm{O}_{2}$ consumption was 0.88 . After the Ioth min, although the animal continued to eat, both $\mathrm{O}_{2}$ consumption and $\mathrm{CO}_{2}$ production fell. When eating stopped, $\mathrm{CO}_{2}$ production and $\mathrm{O}_{2}$ consumption fell to values slightly higher than those noted before the meal. One feature of the experiment was that during eating the volume per min of the respiration fell markedly and when the meal was consumed it rose to 
values above those observed before feeding began. A second experiment with sheep $C t$ confirmed these findings. $\mathrm{O}_{2}$ consumption rose $47 \%$ and $\mathrm{CO}_{2}$ production $70 \%$ from the $5^{\text {th }}$ to the roth min during feeding, and after feeding they fell to values 9 and ${ }_{13} \%$ respectively above prefeeding levels.

During the course of experiments on the effect of environmental temperature on sheep (Joyce \& Blaxter, 1964), body surface temperatures were recorded continuously when the sheep were in the chambers. When the sheep were fed, an immediate vasoconstriction of the legs occurred which lasted for 10-15 min. This response was recorded on many occasions. Furthermore, it could be elicited by sham feeding, that is by operating the control mechanism of an empty manger, the animals being well accustomed to hearing this noise when they were fed.

These observations together with those for $\mathrm{O}_{2}$ consumption suggest that the large increase in metabolism which occurs during the 1 st $h$ of feeding can be ascribed to the act of eating rather than to the specific dynamic effect of food in its classical sense. Neural or hormonal effects may be involved.

\section{Pathological findings in tracheostomized sheep}

The nature of the callus was investigated in the sheep that were killed and will be reported elsewhere by P. S. Blackburn.

\section{DISCUSSION}

Measurements of the gaseous exchange of tracheostomized sheep, though simple to make, are difficult to convert into estimates of heat production. As was recognized many years ago (Klein, 1915), the exchange of gas from the lung differs from that of the whole animal. A large amount of $\mathrm{CH}_{4}$ and a still larger amount of $\mathrm{CO}_{2}$ are not measured, for they are belched by the sheep. The $\mathrm{O}_{2}$ consumption measured from the pulmonary exchange is, however, the same as that measured by confining the animal in a chamber. The experiments show that the discrepancy between the total amount of $\mathrm{CH}_{4}$ produced and that collected from the lungs is not constant but varies with the amount of food given and the amount of fermentation elicited. About $83 \%$ of the $\mathrm{CH}_{4}$ produced is not excreted by the lungs and is lost, presumably by belching. This value is higher than that of $70 \%$ found by Klein (1915). A correction could be made to the values obtained in measurements of pulmonary excretion to take belching into account by multiplying the measured $\mathrm{CH}_{4}$ excretion by the lungs by 6 , since about one-sixth of the total $\mathrm{CH}_{4}$ is collected.

With $\mathrm{CO}_{2}$ production, the discrepancy between total production and the pulmonary exchange is small when small amounts of food are given and increases markedly when the amount of food given is large. Moreover, indirect evidence suggests that during feeding the loss of $\mathrm{CO}_{2}$ is proportionally greater than it is between meals. From equations I and 2, an expression could be derived for the prediction of total $\mathrm{CO}_{2}$ production from the measured pulmonary loss of $\mathrm{CH}_{4}$ and $\mathrm{CO}_{2}$ which would apply to conditions operating in the $9 \mathrm{~h}$ before a meal. Such an expression would not apply to the pulmonary exchange measured during and immediately after feeding and might well not apply to diets other than those used in this experiment. 
There are several alternative methods for estimating heat production when a respiratory quotient cannot be calculated because values are not available for $\mathrm{CO}_{2}$ and $\mathrm{CH}_{4}$ production. One is to multiply the observed $\mathrm{O}_{2}$ consumption by some mean calorie equivalent $/ 1$. A usual equivalent is $4.80 \mathrm{kcal} / \mathrm{l}$., corresponding to a respiratory quotient of 0.8 . This procedure results in overestimating the heat production by $3 \%$ if the animal is fasting and in underestimating it by $7 \%$ if the animal is synthesizing large amounts of fat, that is when the true $R Q$ is $I \cdot I$. An alternative method is to measure the calorie equivalent of $\mathrm{O}_{2}$ in the respiration chamber over a similar period and with the same diet as that used in experiments in which the pulmonary cxchange is measured. This method would undoubtedly reduce errors compared with the first, but it must be emphasized that estimation of heat production over short periods, even when the total $\mathrm{CO}_{2}$ produced and $\mathrm{O}_{2}$ consumed can be measured, could lead to error, particularly during a meal. It appears from comparison of the results of collections of gas from the lungs and in the chamber that large amounts of $\mathrm{CO}_{2}$ can be lost during feeding with a consequent elevation of the RQ. The incremental RQs are so large (over 2.0) that they clearly indicate that the conditions for estimating heat from $\mathrm{O}_{2}$ consumption and $\mathrm{CO}_{2}$ production, namely complete dissimilation of the substrate oxidized, have not been met. Under these conditions, unless the precise nature of the partial dissimilation is known, the calculation is invalid.

A further difficulty encountered in measuring the respiratory exchange with tracheostomized sheep is that such preparations are difficult to maintain for long periods. Only one animal out of seven survived for over i i months without a stenosis of the trachea, and in some stenosis occurred in only a matter of weeks after the operation. In any protracted investigation, uncertainty about the expectation of life of the animals is a serious consideration. It is our experience that, except in those experiments in which it is essential that the face and mouth should not be obstructed, the use of a face mask is superior to tracheostomy as a routine method of collecting expired air from sheep.

\section{SUMMARY}

I. Methods of preparing permanent fistulas of the trachea and of collecting, measuring and analysing the expired gas from the lungs of sheep are described.

2. When sheep stood in a respiration chamber oxygen consumption increased. The increase was small and probably amounted to an increase in energy expenditure of $5-6 \%$.

3. $\mathrm{O}_{2}$ consumption of sheep measured by a Douglas bag technique was the same as that measured by confinement of the same sheep given the same food in a respiration chamber.

4. Methane production from the lungs was only $17 \%$ of that determined in the respiration chamber and this percentage did not vary with the amount of food given. Carbon dioxide production from the lungs was also less than that determined in the respiration chamber, the discrepancy being negligible at low feeding levels and increasing markedly at high feeding levels. The discrepancy is presumed to be due to belching. 
5. Indirect evidence is presented to show that during the act of eating even greater amounts of $\mathrm{CO}_{2}$ are belched. Direct determination of $\mathrm{O}_{2}$ consumption and $\mathrm{CO}_{2}$ production from the pulmonary exchange during eating showed that considerable $(50-60 \%)$ increases in $\mathrm{O}_{2}$ consumption occurred between the $5^{\text {th }}$ and roth min after feeding and were accompanied by expiration of slightly greater volumes of $\mathrm{CO}_{2}$, associated with vasoconstriction of the legs.

6. Methods of calculating heat production of sheep from measurements of their pulmonary exchange of $\mathrm{O}_{2}, \mathrm{CO}_{2}$ and $\mathrm{CH}_{4}$ are discussed, and it is concluded that tracheostomized sheep are useful experimental animals in a limited type of experiment only.

\section{REFERENCES}

Colvin, H. W., Wheat, J. D., Rhode, E. A. \& Boda, J. M. (1957). F. Dairy Sci. 40, 492.

Cresswell, E. (1961). Emp. F. exp. Agric. 29, 162.

Cresswell, E. \& Harris, L. E. (196I). Vet. Rec. 73, 343.

Dougherty, R. W. (196I). In Digestive Physiology and Nutrition of the Ruminant, p. 79. [D. Lewis, editor.] London: Butterworths.

Flatt, W. P., Waldo, D. R., Sykes, J. F. \& Moore, L. A. (1958). E.A.A.P. Publ. no. 8, p. ror.

Hall, W. C. \& Brody, S. (1933). Res. Bull. Mo. agric. Exp. Sta. no. 180.

Joyce, J. P. \& Blaxter, K. L. (1964). Brit. F. Nutr. 18. (In the Press.)

Klein, W. (1915). Biochem. Z. 72, 169.

Pullar, J. (1962). Rep. Rowett Inst. 18, p. 46.

Wainman, F. W. \& Blaxter, K. L. (1958). E.A.A.P. Publ. no. 8, p. 85 .

Webster, W. M. \& Cresswell, E. (1957). Vet. Rec. 69, 526. 